Article

\title{
Screening for Selective Anticancer Activity of Plants from Grazalema Natural Park, Spain
}

José Manuel Calderón-Montaño ${ }^{1}$, Sara María Martínez-Sánchez ${ }^{2}$, Estefanía Burgos-Morón ${ }^{1}$, Emilio Guillén-Mancina ${ }^{1}$, Julio José Jiménez-Alonso ${ }^{1}$, Felipe García ${ }^{2}$, Abelardo Aparicio ${ }^{2}$, Miguel LópezLázaro ${ }^{1, *}$

${ }^{I}$ Department of Pharmacology, Faculty of Pharmacy, University of Seville, Sevilla, Spain

${ }^{2}$ Department of Vegetal Biology and Ecology, Faculty of Pharmacy, University of Seville, Sevilla, Spain

\begin{abstract}
Although several plant-derived drug groups (vinca alkaloids, taxanes, podophyllotoxin derivatives and camptothecins) continue to be widely used in cancer therapy, the anticancer potential of the Plant Kingdom remains largely unexplored. In this work, we have carried out a random screening for selective anticancer activity of 57 extracts from 45 plants collected in Grazalema Natural Park, an area in the South of Spain of high plant diversity and endemism. Using lung cancer cells (A549) and lung non-malignant cells (MRC-5), we found that several extracts were more cytotoxic and selective against the cancer cell line than the standard anticancer agent cisplatin. Five active extracts were further tested in cancer and normal cell lines from other tissues, including three skin cell lines with increasing degree of malignancy. An extract from the leaves of Daphne laureola L. (Thymelaeaceae) showed a striking potency and selectivity on lung cancer cells and leukemia cells; the $\mathrm{IC}_{50}$ values against these cancer cells were approximately 10000 -fold lower than against the normal cells. Daphnane-type diterpene orthoesters may be responsible for this highly selective anticancer activity.
\end{abstract}

Keywords: cancer; lung cancer; leukemia; Daphne; Thapsia; daphnane diterpenes

\section{Introduction}

Several plant-derived compounds continue to be widely used in cancer therapy. The plantderived anticancer drug family comprises the vinca alkaloids vincristine and vinblastine (two indole alkaloids isolated from Catharanthus roseus G. Don., Apocynaceae) and their semisynthetic analogs vindesine and vinorelbine, the taxane paclitaxel (a diterpene isolated from the bark of Taxus brevifolia Nutt., Taxaceae) and their semisynthetic derivatives docetaxel and cabazitaxel, the podophyllotoxin derivatives etoposide and teniposide (semi-synthetic analogues of the natural lignane podophyllotoxin, isolated from Podophyllum species, Podophyllaceae), and the campthothecins irinotecan and topotecan (analogues of the quinoline alkaloid camptotethin, isolated from Camptotheca acuminata Decne, Nyssaceae). More recently, omacetaxine (a semisynthetic analog of the alkaloid homoharringtonine, isolated from Cephalotaxus harringtonii (Knight ex J.Forbes) K.Koch, Cephalotaxaceae) received approval for patients with chronic myeloid leukemia when tyrosine kinase inhibitors fail [1-4]. Some of these plant-derived drugs are considered essential medicines by the World Health Organization for the treatment of a variety of cancers. The "WHO model list of essential medicines" ( $20^{\text {th }}$ edition) includes vincristine (acute lymphoblastic leukemia, diffuse large B-cell lymphoma, Hodgkin lymphoma, Burkitt lymphoma, follicular lymphoma, Kaposi sarcoma, retinoblastoma, rhabdomyosarcoma, Ewing sarcoma, Wilms tumor and gestational 
trophoblastic neoplasia), vinblastine (Hodgkin lymphoma, Kaposi sarcoma, testicular germ cell tumor and ovarian germ cell tumor), vinorelbine (non-small cell lung cancer and metastatic breast cancer), paclitaxel (epithelial ovarian cancer, early stage breast cancer, metastatic breast cancer, Kaposi sarcoma, nasopharyngeal cancer, non-small cell lung cancer and ovarian germ cell tumor), docetaxel (early stage breast cancer, metastatic breast cancer and metastatic prostate cancer), etoposide (testicular germ cell tumor, gestational trophoblastic neoplasia, Hodgkin lymphoma, nonsmall cell lung cancer, ovarian germ cell tumor, retinoblastoma, Ewing sarcoma, acute lymphoblastic leukemia and Burkitt lymphoma), and irinotecan (metastatic colorectal cancer).

Although several plants have provided useful drugs for the treatment of a variety of cancers, the anticancer potential of the Plant Kingdom remains largely unexplored. Of the approximately 400,000 land plant species known worldwide [5,6], it has been estimated that less than $20 \%$ have ever been studied for potential therapeutic effects, and a smaller percentage for anticancer activity [2]. These data suggest that an unknown number of plants with potentially useful anticancer compounds are waiting to be discovered.

Grazalema Natural Park is an area in the South of Spain of high plant diversity and endemism. Because of its position as one of the first mountain barriers to the moisture-laden winds from the Atlantic Ocean, this UNESCO Biosphere Reserve is characterized by an extraordinarily rainy microclimate. With an annual rainfall of over $2000 \mathrm{~mm}$, more than 1000 plant species (many of them endemic and some of them unique) flourish in this ecologically rich area $[7,8]$. Evidence suggests that random screening of plants from regions of high biodiversity and endemism may lead to novel drug discovery, because the biodiversity of organisms can lead to chemical diversity of their natural products and therefore to a wide range of pharmacological modulators [9]. The discovery of the anticancer agent paclitaxel from the bark of Taxus brevifolia Nutt. was made following a random screening approach [9].

Using cancer and normal cell lines, we have evaluated the selective anticancer activity of 57 extracts from 45 plants collected in Grazalema Natural Park following a patient-oriented screening approach [10-12], and report the results in this paper.

\section{Material and Methods}

\subsection{Plant material}

All plants were collected in June 2013 in Grazalema Natural Park by Dr. Felipe Garcia. Collection was non-destructive and plat specimens (20-100g) were carefully selected to avoid any damage that could affect the conservation of any species, particularly those in the "Red list of threatened species". A voucher specimen was deposited in the herbarium at the Department of Vegetal Biology and Ecology, Faculty of Biology, University of Seville. The botanical names, plant parts and voucher specimen numbers are listed in Table 1.

\subsection{Preparation of the extracts}

Fresh plant material (20-100g) was extracted with $100-150 \mathrm{~mL}$ of ethanol/ethyl acetate/water $(1: 1: 1)$ at $60^{\circ} \mathrm{C}$ for 1 hour by using an ultrasound water bath apparatus. After vacuum filtration, the ethanol and ethyl acetate solvents were eliminated in a rotary vacuum evaporator at $60^{\circ} \mathrm{C}$. Finally, the remaining water solution was lyophilized to yield dried extracts. The extraction yield for each extract (see identification number in Table 1) was: 1 (3.2\%), 2 (5.9\%), 3 (7.5\%), 4 (5.5\%), 5 (4.3\%), 6 (1.9\%), 7 (6.6\%), 8 (10.9\%), 9 (4.6\%), 10 (9.9\%), 11 (4.5\%), 12 (8.5\%), 13 (10.0\%), 14 (2.3\%), 15 (7.8\%), 16 (6.1\%), 17 (5.0\%), 18 (3.5\%), 19 (6.1\%), 20 (4.1\%), 21 (5.1\%), 22 (3.5\%), 23 (5.7\%), 24 
(8.0\%), 25 (6.5\%), $26(2.7 \%), 27$ (5.4\%), 28 (3.0\%), $29(5.4 \%), 30(4.8 \%), 31(6.6 \%), 32(4.0 \%), 33$ (3.7\%), 34 (3.7\%), 35 (4.7\%), 36 (2.5\%), 37 (4.7\%), 38 (2.5\%), 39 (4.8\%), 40 (3.9\%), 41 (6.0\%), 42 (6.5\%), 43 (7.1\%), 44 (4.2\%), 45 (5.8\%), 46 (N.D.), 47 (1.7\%), 48 (1.7\%), 49 (2.2\%), 50 (7.3\%), 51 $(5.0 \%), 52$ (4.9\%), 53 (0.6\%), 54 (N.D.) 55 (6.2\%), 56 (5.1\%) and 57 (4.4\%). The extracts were stored in dark glass bottles and kept in a cool dark place. A part of each extract was dissolved in DMSO $(100 \mathrm{mg} / \mathrm{mL})$ and aliquots were stored at $-80^{\circ} \mathrm{C}$. To detect the possible degradation of active compounds of the extracts, the first independent MTT experiment was carried out within the first month after collecting the plant. In one of the three independent experiments, the extract was dissolved the day of the experiment. The rest of independent experiments were carried out using the aliquots stored at $-80^{\circ} \mathrm{C}$.

\subsection{Chemicals and cell lines}

Cisplatin, MTT (3-(4,5-dimethylthiazol-2-yl)-2,5-diphenyltetrazolium bromide) and resazurin were obtained from Sigma. A549 (human lung adenocarcinoma cells) and MRC-5 (human lung fibroblastic cells) were purchased from European Collection of Cell Cultures. VH10 (human foreskin fibroblast cells), HepG2 (human hepatocellular carcinoma cells), SW480 (human colon adenocarcinoma cells), U2OS (human osteosarcoma cells), HeLa (human cervical carcinoma cells), PC3 (human prostate cancer cells), MCF7 (human breast cancer cells), HL-60 (human acute promyelocytic leukemia cells) and NB4 (human acute promyelocytic leukemica cells) were generously provided by Dr. Helleday (Karolinska Institute, Sweden). BJ-hTERT (hTERTimmortalized foreskin fibroblast BJ cells), BJ-SV40T (SV40T-transformed BJ-hTERT cells), and BJ-RASV12 (H-RAS V12-transformed BJ-SV40T cells) were kindly provided by Dr. Hahn (DanaFarber Cancer Institute, USA) [13]. A549, MRC-5, VH10, HepG2, SW480, U2OS, HeLa, MCF7, BJ-hTERT, BJ-SV40T and BJ-RASV12 were grown in DMEM high glucose medium (Gibco). PC3 was grown in DMEM-F12 (Gibco). HL60 and NB4 were cultured in RPMI 1640 (Gibco). All media were supplemented with $10 \%$ fetal bovine serum and $1 \%$ penicillin-streptomycin solution. All cells were cultured at $37{ }^{\circ} \mathrm{C}$ in a humidified atmosphere containing $5 \% \mathrm{CO}_{2}$. Cell culture reagents were purchased from Thermo Fisher Scientific.

\subsection{Cell proliferation assays}

The MTT assay and the resazurin assay are widely used to estimate cell viability. The MTT assay is based on the ability of viable cells to convert the MTT compound (3-(4,5-dimethylthiazol-2yl)-2,5-diphenyltetrazolium bromide) into an insoluble and purple formazan product; dead cells are metabolically inactive and cannot reduce the MTT into the colored compound. After an incubation period of the cells with the MTT and a solubilization step, the quantity of the colored product is measured with a plate reading spectrophotometer. The resazurin assay is a redox-based colorimetric or fluorometric assay based on the capacity of viable cells to reduce the blue compound resazurin into the pink, fluorescent and soluble product resorufin. The quantity of resorufin produced is proportional to the number of viable cells. In both assays, the cells were previously seeded in 96well plates and were allowed to grow during $24 \mathrm{~h}$. The cells were then exposed to several concentrations of the extracts or cisplatin during $72 \mathrm{~h}$. In the MTT assay, after the 72-h treatment period, the medium was removed and $125 \mu \mathrm{L}$ MTT ( $1 \mathrm{mg} / \mathrm{mL}$ in medium) was added to each well. Four hours later, $80 \mu \mathrm{L} 20 \%$ SDS in $0.02 \mathrm{M} \mathrm{HCl}$ were added to the wells. The plates were incubated overnight at $37^{\circ} \mathrm{C}$ before measuring optical densities at $540 \mathrm{~nm}$ using an absorbance spectrophotometer microplate reader. In the resazurin assay, after the 72-h treatment period, $100 \mu \mathrm{L}$ of resazurin dissolved in culture medium were added to each well to obtain a final concentration of $10 \mu \mathrm{g} / \mathrm{mL}$. One hour later, fluorescence intensity was read at 530/590 nm (excitation/emission) using 
a fluorescence microplate reader. Cell viability was expressed as percentage in relation to controls (untreated cells) in both assays.

All data were averaged from 2-7 independent experiments. Although most extracts were tested in 3 independent experiments, the third experiment was not conducted for some extracts when two independent experiments revealed no cytotoxicity in both cell lines. Other extracts were tested more than three times; these additional experiments were carried out when substantial discrepancies in the concentration-response curves were observed or to confirm a marked cytotoxicity or selectivity. After estimating cell viability and calculating $\mathrm{IC}_{50}$ values, results were expressed as mean \pm standard error of the mean (SEM), and a $t$-test (paired, two tailed) was used for statistical analysis. A $P$ value $>0.05$ is not considered statistically significant and is not represented by any symbol. A $P$ value $\leq 0.05$ is considered statistically significant and is represented with an asterisk, two asterisks ( $P$ $\leq 0.01)$ or three asterisks $(P \leq 0.001)$. Because selectivity is the most important parameter to detect anticancer potential in vitro [10-12] selectivity indices were used to quantify this parameter. The selectivity index (S.I.) was calculated as the average of the $\mathrm{IC}_{50}$ value in the normal cell line divided by the $\mathrm{IC}_{50}$ value in the cancer cell line obtained in each independent experiment [11].

\section{Results and discussion}

Using lung cancer cells (A549) and lung non-malignant cells (MRC-5), we have screened the selective anticancer activity of 57 extracts from 45 plant species collected in Grazalema Natural Park (Andalusia, Spain). Table 1 shows the botanical names (in alphabetical order) and families, an identification number for each extract, the $\mathrm{IC}_{50}$ value in the MTT assay for both cell line, and the selectivity index. Dose-response curves for the 57 extracts are provided in Figures 1-5. Results show that several extracts were more cytotoxic and selective against the cancer cell line than the standard anticancer agent cisplatin. Two extracts from the fruits and leaves of Daphne laureola L. (Thymelaeaceae, extracts $\mathbf{2 2}$ and 23) and an extract from the flowering aerial parts of Thapsia villosa L. (Apiaceae, extract 51) showed the highest cytotoxic activity against the lung cancer cell line. Importantly, extracts $\mathbf{2 2}$ and $\mathbf{2 3}$ also showed a high selectivity index. The extract from the leaves of Echinops strigosus L. (Compositae, extract 27), the extract from the leaves of Ceratonia siliqua L. (Leguminosae, extract 16), and the extract from the aerial parts of Iberis carnosa Willd. subsp. granatensis (Boiss. \& Reut.) Moreno (Brassicaceae, extract 32) also showed some degree of selectivity against the cancer cell line (selectivity index $>10$ ). Several extracts (e.g., 8, 11, 26) did not show clear cytotoxic effects at the maximum tested concentration $(1000 \mu \mathrm{g} / \mathrm{mL})$. Many extracts were cytotoxic but were not selective against the cancer cells, and one of them (extract 45) was clearly more toxic against the normal cell line than against the cancer cell line (see Table 1 and Figures 1-5).

Extracts 22, 23, 27, 32 and 51, and the standard anticancer drug cisplatin, were tested for cytotoxic activity with the resazurin assay in 12 additional human cell lines: 6 cancer cell lines derived from solid tumors of different tissues (liver, colon, bone, cervix, prostate and breast), 2 acute promyelocytic leukemia cell lines, a normal skin cell line, and three genetically modified skin cell lines with increasing degree of malignancy. Table 2 and Figure 6 show that extracts 27, 32 and $\mathbf{5 1}$ did not show a marked selective anticancer activity against any of the cancer cell lines. However, extracts 22 and $\mathbf{2 3}$ (from the fruits and leaves of Daphne laureola L.) showed a striking selectivity against the two acute promyelocytic leukemia cell lines (NB4 and HL60). The cytotoxicity of these two extracts against the leukemia cell lines was approximately 10000-100000 times higher than for the normal cell line and the rest of cancer cell lines (Table 2 and Figure 6). The anticancer drug cisplatin also showed an important selectivity towards the leukemia cell lines; however, this 
anticancer agent was approximately 100-1000 times less selective than the extracts from Daphne laureola L (Figure 6). In addition, the cytotoxicity of these extracts increased in three genetically modified cell lines (BJ-hTERT, BJ-SV40T and BJ-RASV12) [13] as their degree of malignancy increased (Table 2).

The marked cytotoxic activity of the extract from Thapsia villosa L. (extract 51) may be mediated by guaianolide sesquiterpene lactones related to thapsigargin [14,15]. Thapsigargin, isolated from Thapsia garganica L., is a potent inhibitor of the sarcoplasmic/endoplasmic reticulum calcium ATPase (SERCA) pump. Inhibition of the SERCA pump by thapsigargin depletes endoplasmic reticulum calcium stores, triggering the opening of plasma membrane calcium channels. This leads to a rapid increase in the cytosolic concentration of calcium that eventually results in cell death. Although thapsigargin has a limited selectivity towards cancer cells (and therefore a limited therapeutic potential), the thapsigargin-based prodrug mipsagargin has reached clinical trials for cancer therapy. This prodrug achieves higher concentrations of thapsigargin at the tumor site, thereby limiting to some extent its toxicity towards normal cells $[15,16]$.

Daphnane-type diterpene orthoesters may be responsible for the highly selective anticancer activity of our extracts from Daphne laureola L. The daphnane-type diterpene mezerein, isolated from Daphne mezereum L., exerted a potent antileukemic activity against the P-388 lymphocytic leukemia in mice [17]. Importantly, other daphnane-type diterpene orthoesters, isolated from Daphne genkwa Siebold \& Zucc., displayed over 1000-fold greater cytotoxicity against A549 human lung cancer cells versus MRC-5 normal lung cells $[18,19]$. The daphnane orthoester yuanhuapin also showed a marked cytotoxicity against $\mathrm{A} 549$ cells $\left(\mathrm{IC}_{50}=150 \mathrm{nM}\right)$ and $\mathrm{K} 562$ chronic myeloid leukemia cells $\left(\mathrm{IC}_{50}=7 \mathrm{nM}\right)[20]$. These data are in agreement with our results, and suggest that the highly selective anticancer activity shown by of our extracts against lung cancer cells and promyelocytic leukemia cells may be mediated by this type of terpenes.

The anticancer potential of daphnanes has not been fully pursued probably because these compounds are commonly regarded as possible tumor promoters. Tyglianes-type diterpenes such as phorphol and several of its esters (e.g., 12-O-tetradecanoylphorbol-13-acetate, also known as phorbol 12-myristate 13-acetate, TPA or PMA) are potent tumor promoters commonly used in carcinogenesis experiments. These tumor promoters activate the signal transduction enzyme protein kinase $\mathrm{C}$ (PKC) by mimicking the second messenger diacylglycerol (DAG), which is a physiological activator of PKC. Sustained activation of PKC can lead to activation of complex pathways involved in cell cycle progression, tumorigenesis and metastasis [21]. Since daphnanes and tyglianes are chemically related and some daphnanes can also target PKC [20,22], it is often assumed that daphnanes may have tumorigenic properties rather than anticancer activities. However, it is well known that chemically-related compounds can either activate or inhibit a pharmacological target and result in opposite effects depending on small chemical variations; this seems to be the case for some phorbol esters and related analogs [23]. In addition, there are numerous PKC isoenzymes and, although the expression of many PKC isoenzymes is altered in multiple cancer types, the effect of individual PKC isozymes on cancer remains poorly understood [21]. Similar compounds can target different isoenzymes and lead to different effects. Therefore, the structural and pharmacological similarities between tyglianes and daphnanes should not be a barrier to develop daphnane-type diterpene orthoesters as potential anticancer agents.

It is important to be reminded that the key feature of a clinically useful anticancer drug is its ability to selectively kill cancer cells; the cytotoxic potency and the pharmacological target are irrelevant parameters in the absence of selectivity [10-12]. Our work shows that the selectivity of two extracts from Daphne laureola L. towards lung cancer cells and leukemia cells is unusually 
high. Similar degree of selectivity has been observed in the same cancers by daphnane-type diterpene orthoesters isolated from other species of the genus Daphne. According to "The Plant List" database, there are over 100 different species of the genus Daphne; the anticancer potential of most of these species remains unexplored. Synthesis or semisynthesis of daphnane-type diterpene orthoesters with improved anticancer activities may also be feasible [20]. The high selectivity of Daphne species and daphnane-type diterpene orthoesters towards cancer cells deserves additional studies.

\section{Conflicts of Interest}

The authors declare no conflict of interest.

\section{References}

1. Cragg GM, Newman DJ. Plants as a source of anti-cancer agents. J. Ethnopharmacol. 2005; 100(1-2): $72-79$.

2. Cragg GM, Grothaus PG, Newman DJ. Impact of natural products on developing new anticancer agents. Chem. Rev. 2009; 109(7): 3012-3043.

3. Kingston DG, Newman DJ. The search for novel drug leads for predominately antitumor therapies by utilizing mother nature's pharmacophoric libraries. Curr. Opin. Drug Discov. Devel. 2005; 8(2): 207-227.

4. Newman DJ, Cragg GM. Natural Products as Sources of New Drugs from 1981 to 2014. J Nat Prod. 2016; 79(3): 629-661.

5. Lughadha EN, Govaerts R, Belyaeva I, Black N, Lindon H, Allkin R, Magill RE, Nicolson N. Counting counts: Revised estimates of numbers of accepted species of flowering plants, seed plants, vascular plants and land plants with a review of other recent estimates. Phytotaxa 2016; 272(1): 82-88 http://dx.doi.org/10.11646/phytotaxa.272.1.5.

6. Ulloa UC, Acevedo-Rodriguez P, Beck S, Belgrano MJ, Bernal R, Berry PE, Brako L, Celis M, Davidse G, Forzza RC, Gradstein SR, Hokche O, Leon B et al. An integrated assessment of the vascular plant species of the Americas. Science. 2017; 358(6370): 1614-1617.

7. Valdés Castrillón, B; Talavera Lozano, S \& Fernández-Galiano Fernández, E (eds.) (1987). Flora vascular de Andalucía Occidental, Ketres Editora S.A. Barcelona. ISBN: 84-8525663-8 http://www.jolube.es/entrada jolube FVA.htm

8. Blanca G, Cabezudo B, Cueto M, Salazar C \& Morales Torres C. (2011, eds.). Flora Vascular de Andalucía Oriental. $2^{\mathrm{a}}$ Edición. http://www.jolube.es/entrada jolube FVA.htm

9. Atanasov AG, Waltenberger B, Pferschy-Wenzig EM, Linder T, Wawrosch C, Uhrin P, Temml V, Wang L, Schwaiger S, Heiss EH, Rollinger JM, Schuster D, Breuss JM et al. Discovery and resupply of pharmacologically active plant-derived natural products: A review. Biotechnol. Adv. 2015; 33(8): 1582-1614.

10. Lopez-Lazaro M. How many times should we screen a chemical library to discover an anticancer drug? Drug Discov. Today 2015; 20(2): 167-169.

11. Lopez-Lazaro M. A Simple and Reliable Approach for Assessing Anticancer Activity In Vitro. Curr. Med. Chem. 2015; 22(11): 1324-1334. 
12. Lopez-Lazaro M. Two preclinical tests to evaluate anticancer activity and to help validate drug candidates for clinical trials. Oncoscience 2015; 2(2): 91-98.

13. Hahn WC, Counter CM, Lundberg AS, Beijersbergen RL, Brooks MW, Weinberg RA. Creation of human tumour cells with defined genetic elements. Nature 1999; 400(6743): 464-468.

14. Rubal JJ, Moreno-Dorado FJ, Guerra FM, Jorge ZD, Galan MC, Salido GM, Christensen SB, Sohoel H, Massanet GM. A phenylpropanoid, a slovenolide, two sulphur-containing germacranes and Ca2+-ATPase inhibitors from Thapsia villosa. Planta Med. 2010; 76(3): 284-290.

15. Andersen TB, Lopez CQ, Manczak T, Martinez K, Simonsen HT. Thapsigargin--from Thapsia L. to mipsagargin. Molecules 2015; 20(4): 6113-6127.

16. Mahalingam D, Wilding G, Denmeade S, Sarantopoulas J, Cosgrove D, Cetnar J, Azad N, Bruce J, Kurman M, Allgood VE, Carducci M. Mipsagargin, a novel thapsigargin-based PSMA-activated prodrug: results of a first-in-man phase I clinical trial in patients with refractory, advanced or metastatic solid tumours. Br. J Cancer. 2016; 114(9): 986-994.

17. Kupchan SM, Baxter RL. Mezerein: antileukemic principle isolated from Daphne mezereum L. Science. 1975; 187(4177): 652-653.

18. Hong JY, Nam JW, Seo EK, Lee SK. Daphnane diterpene esters with anti-proliferative activities against human lung cancer cells from Daphne genkwa. Chem. Pharm. Bull. (Tokyo). 2010; 58(2): 234-237.

19. Jo SK, Hong JY, Park HJ, Lee SK. Anticancer Activity of Novel Daphnane Diterpenoids from Daphne genkwa through Cell-Cycle Arrest and Suppression of Akt/STAT/Src Signalings in Human Lung Cancer Cells. Biomol. Ther (Seoul. ) 2012; 20(6): 513-519.

20. Wender PA, Buschmann N, Cardin NB, Jones LR, Kan C, Kee JM, Kowalski JA, Longcore KE. Gateway synthesis of daphnane congeners and their protein kinase $\mathrm{C}$ affinities and cellgrowth activities. Nat Chem. 2011; 3(8): 615-619.

21. Garg R, Benedetti LG, Abera MB, Wang H, Abba M, Kazanietz MG. Protein kinase C and cancer: what we know and what we do not. Oncogene. 2014; 33(45): 5225-5237.

22. Saraiva L, Fresco P, Pinto E, Portugal H, Goncalves J. Differential activation by daphnetoxin and mezerein of PKC-isotypes alpha, beta I, delta and zeta. Planta Med. 2001; 67(9): 787-790.

23. Kazanietz MG, Caloca MJ, Eroles P, Fujii T, Garcia-Bermejo ML, Reilly M, Wang H. Pharmacology of the receptors for the phorbol ester tumor promoters: multiple receptors with different biochemical properties. Biochem. Pharmacol. 2000; 60(10): 1417-1424. 
Table 1. Screening of selective anticancer activity of plant extracts from Grazalema Natural Park against A549 lung cancer cells and MRC-5 lung normal cells (MTT assay).

\begin{tabular}{|c|c|c|c|c|c|c|}
\hline & \multirow{2}{*}{ Plant name (Family) } & \multirow{2}{*}{ Part used } & \multirow{2}{*}{$\begin{array}{l}\text { Voucher } \\
\text { number } \\
\text { (SEV-) }\end{array}$} & \multicolumn{2}{|c|}{$\mathrm{IC}_{50}(\mathrm{Mean} \pm \mathrm{SEM}, \mu \mathrm{g} / \mathrm{ml})$} & \multirow{2}{*}{ S.I. } \\
\hline & & & & $\begin{array}{l}\text { A549 } \\
\text { (Cancer) }\end{array}$ & $\begin{array}{l}\text { MRC-5 } \\
\text { (Normal) }\end{array}$ & \\
\hline 1 & Abies pinsapo Boiss. (Pinaceae) & Bark & 284642 & $23.8 \pm 4.9$ & $130.8 \pm 47.5$ & 5.5 \\
\hline 2 & Abies pinsapo Boiss. (Pinaceae) & Leaves & 284642 & $86.1 \pm 31.7$ & $146.4 \pm 17.2$ & 2.4 \\
\hline 3 & $\begin{array}{l}\text { Acer monspessulanum } \mathrm{L} . \\
\text { (Sapindaceae) }\end{array}$ & Leaves & 284617 & $39.4 \pm 22.6$ & $102.5 \pm 50.3$ & 3.2 \\
\hline 4 & $\begin{array}{l}\text { Acinos alpinus Moench } \\
\text { (Lamiaceae) }\end{array}$ & $\begin{array}{l}\text { Whole } \\
\text { plant }\end{array}$ & 284607 & $529.9 \pm 227.5$ & $740.0 \pm 370.4$ & 1.3 \\
\hline 5 & $\begin{array}{l}\text { Anthyllis cytisoides } \mathrm{L} . \\
\text { (Leguminosae) }\end{array}$ & $\begin{array}{l}\text { Aerial } \\
\text { Parts }\end{array}$ & 284619 & $269.0 \pm 6.8$ & $372.3 \pm 11.0$ & 1.4 \\
\hline 6 & $\begin{array}{l}\text { Anthyllis polycephala Desf. } \\
\text { (Leguminosae) }\end{array}$ & Bark & 284649 & $>1000$ & $>1000$ & N.D. \\
\hline 7 & $\begin{array}{l}\text { Antirrhinum graniticum Rothm. } \\
\text { (Plantaginaceae) }\end{array}$ & Flowers & 284608 & $1395.1 \pm 589.7$ & $621.4 \pm 220.6$ & 0.6 \\
\hline 8 & $\begin{array}{l}\text { Antirrhinum graniticum Rothm. } \\
\text { (Plantaginaceae) }\end{array}$ & Leaves & 284608 & $>1000$ & $>1000$ & N.D. \\
\hline 9 & $\begin{array}{l}\text { Asperula hirsuta Desf. } \\
\text { (Rubiaceae) }\end{array}$ & $\begin{array}{l}\text { Whole } \\
\text { plant }\end{array}$ & 284640 & $268.9 \pm 15.2$ & $341.3 \pm 23.9$ & 1.3 \\
\hline 10 & $\begin{array}{l}\text { Berberis vulgaris subsp. australis } \\
\text { (Boiss.) Heywood (Berberidaceae) }\end{array}$ & $\begin{array}{l}\text { Aerial } \\
\text { Parts }\end{array}$ & 284618 & $205.2 \pm 18.9$ & $269.8 \pm 31.0$ & 1.3 \\
\hline 11 & $\begin{array}{l}\text { Biscutella auriculata } \mathrm{L} . \\
\text { (Brassicaceae) }\end{array}$ & $\begin{array}{l}\text { Aerial } \\
\text { Parts }\end{array}$ & 284633 & $>1000$ & $>1000$ & N.D. \\
\hline 12 & $\begin{array}{l}\text { Bupleurum spinosum Gouan } \\
\text { (Apiaceae) }\end{array}$ & Leaves & 284612 & $94.9 \pm 14.4$ & $357.7 \pm 152.3$ & 3.5 \\
\hline 13 & $\begin{array}{l}\text { Campanula specularioides Coss. } \\
\text { (Campanulaceae) }\end{array}$ & $\begin{array}{l}\text { Whole } \\
\text { plant }\end{array}$ & 284641 & $255.1 \pm 10.1$ & $69.8 \pm 20.5$ & 0.3 \\
\hline 14 & $\begin{array}{l}\text { Cerastium gibraltaricum Boiss. } \\
\text { (Caryophyllaceae) }\end{array}$ & $\begin{array}{l}\text { Whole } \\
\text { plant }\end{array}$ & 284635 & $>1000$ & $>1000$ & N.D. \\
\hline 15 & $\begin{array}{l}\text { Ceratonia siliqua } \mathrm{L} . \\
\text { (Leguminosa) }\end{array}$ & Twigs & 284634 & $62.7 \pm 27.5$ & $121.2 \pm 66.2$ & 1.7 \\
\hline 16 & $\begin{array}{l}\text { Ceratonia siliqua } \mathrm{L} . \\
\text { (Leguminosae) }\end{array}$ & Leaves & 284634 & $27.1 \pm 0.5$ & $819.6 \pm 337.5$ & 23.8 \\
\hline 17 & $\begin{array}{l}\text { Cirsium echinatum (Desf.) DC. } \\
\text { (Compositae) }\end{array}$ & Flowers & 284644 & $711.4 \pm 112.0$ & $>1000$ & $>1.2$ \\
\hline 18 & $\begin{array}{l}\text { Cirsium echinatum (Desf.) DC. } \\
\text { (Compositae) }\end{array}$ & Leaves & 284644 & $>1000$ & $>1000$ & N.D. \\
\hline 19 & $\begin{array}{l}\text { Crataegus monogyna Jacq. } \\
\text { (Rosaceae) }\end{array}$ & $\begin{array}{l}\text { Aerial } \\
\text { Parts } \\
\end{array}$ & 284615 & $207.8 \pm 42.5$ & $304.2 \pm 38.6$ & 1.6 \\
\hline 20 & Cynara humilis L. (Compositae) & Flowers & 284636 & $556.6 \pm 153.9$ & $>1000$ & 2.5 \\
\hline 21 & Cynara humilis L. (Compositae) & Leaves & 284636 & $466.5 \pm 83.9$ & $>1000$ & $>2.3$ \\
\hline 22 & $\begin{array}{l}\text { Daphne laureola } \mathrm{L} . \\
\text { (Thymelaeaceae) }\end{array}$ & Fruit & 284643 & $1.8 \pm 1.2$ & $1444.1 \pm 636.8$ & $>1000$ \\
\hline 23 & $\begin{array}{l}\text { Daphne laureola L. } \\
\text { (Thymelaeaceae) }\end{array}$ & Leaves & 284643 & $0.019 \pm 0.003$ & $144.1 \pm 60.8$ & $>10000$ \\
\hline 24 & $\begin{array}{l}\text { Distichoselinum tenuifolium (Lag.) } \\
\text { F.García Mart. \& Silvestre } \\
\text { (Apiaceae) }\end{array}$ & Fruit & 284645 & $179.4 \pm 66.9$ & $257.4 \pm 32.4$ & 2.2 \\
\hline 25 & $\begin{array}{l}\text { Distichoselinum tenuifolium (Lag.) } \\
\text { F.García Mart. \& Silvestre } \\
\text { (Apiaceae) }\end{array}$ & Leaves & 284645 & $220.0 \pm 73.2$ & $469.6 \pm 156.2$ & 8.1 \\
\hline 26 & $\begin{array}{l}\text { Echinops strigosus L. } \\
\text { (Compositae) }\end{array}$ & Flowers & 284631 & $>1000$ & $>1000$ & N.D. \\
\hline 27 & $\begin{array}{l}\text { Echinops strigosus L. } \\
\text { (Compositae) }\end{array}$ & Leaves & 284631 & $23.2 \pm 8.6$ & $219.5 \pm 23.7$ & 15.2 \\
\hline 28 & $\begin{array}{l}\text { Echium albicans Lag. \& Rodr. } \\
\text { (Boraginaceae) }\end{array}$ & $\begin{array}{l}\text { Aerial } \\
\text { Parts }\end{array}$ & 284614 & $1.4 \pm 0.4$ & $2.6 \pm 0.2$ & 2.0 \\
\hline
\end{tabular}




\begin{tabular}{|c|c|c|c|c|c|c|}
\hline & \multirow{2}{*}{ Plant name (Family) } & \multirow{2}{*}{ Part used } & \multirow{2}{*}{$\begin{array}{l}\text { Voucher } \\
\text { number } \\
\text { (SEV-) }\end{array}$} & \multicolumn{2}{|c|}{$\mathrm{IC}_{50}($ Mean \pm SEM, $\mu \mathrm{g} / \mathrm{ml})$} & \multirow{2}{*}{ S.I. } \\
\hline & & & & $\begin{array}{l}\text { A549 } \\
\text { (Cancer) }\end{array}$ & $\begin{array}{l}\text { MRC-5 } \\
\text { (Normal) }\end{array}$ & \\
\hline 29 & $\begin{array}{l}\text { Helianthemum apenninum (L.) } \\
\text { Mill. (Cistaceae) }\end{array}$ & $\begin{array}{l}\text { Whole } \\
\text { plant }\end{array}$ & 284646 & $137.4 \pm 29.2$ & $210.1 \pm 18.3$ & 1.7 \\
\hline 30 & $\begin{array}{l}\text { Helleborus foetidus L. } \\
\text { (Ranunculaceae) }\end{array}$ & Fruit & 284647 & $0.04 \pm 0.02$ & $0.33 \pm 0.18$ & 8.1 \\
\hline 31 & $\begin{array}{l}\text { Helleborus foetidus L. } \\
\text { (Ranunculaceae) }\end{array}$ & Leaves & 284647 & $0.07 \pm 0.03$ & $0.23 \pm 0.04$ & 5.2 \\
\hline 32 & $\begin{array}{l}\text { Iberis carnosa Willd. subsp. } \\
\text { granatensis (Boiss. \& Reut.) } \\
\text { Moreno (Brassicaceae) }\end{array}$ & $\begin{array}{l}\text { Aerial } \\
\text { Parts }\end{array}$ & 284648 & $1.2 \pm 0.3$ & $14.2 \pm 6.0$ & 11.5 \\
\hline 33 & $\begin{array}{l}\text { Lavandula lanata Boiss. } \\
\text { (Lamiaceae) }\end{array}$ & Bark & 284637 & $230.5 \pm 6.8$ & $222.3 \pm 77.7$ & 1.0 \\
\hline 34 & Linum suffruticosum L. (Linaceae) & Root & 284613 & $657.1 \pm 20.3$ & $>1000$ & $>1.5$ \\
\hline 35 & Linum tenue Desf. (Linaceae) & $\begin{array}{l}\text { Whole } \\
\text { plant }\end{array}$ & 284632 & $36.1 \pm 2.2$ & $56.1 \pm 19.9$ & 1.7 \\
\hline 36 & $\begin{array}{l}\text { Mercurialis tomentosa } \mathrm{L} . \\
\text { (Euphorbiaceae) }\end{array}$ & $\begin{array}{l}\text { Aerial } \\
\text { Parts }\end{array}$ & 284625 & $354.0 \pm 8.7$ & $304.1 \pm 15.4$ & 0.9 \\
\hline 37 & $\begin{array}{l}\text { Ononis mitissima } \mathrm{L} . \\
\text { (Leguminosae) }\end{array}$ & $\begin{array}{l}\text { Whole } \\
\text { plant }\end{array}$ & 284639 & $38.8 \pm 8.3$ & $106.0 \pm 78.4$ & 2.2 \\
\hline 38 & $\begin{array}{l}\text { Phlomis } \times \text { composita } \text { Pau } \\
(\text { Lamiaceae) }\end{array}$ & $\begin{array}{l}\text { Aerial } \\
\text { Parts }\end{array}$ & 284629 & $84.5 \pm 13.8$ & $267.4 \pm 35.6$ & 2.8 \\
\hline 39 & Phlomis purpurea L. (Lamiaceae) & $\begin{array}{l}\text { Flowering } \\
\text { aerial } \\
\text { parts }\end{array}$ & 284630 & $184.4 \pm 75.8$ & $417.9 \pm 170.7$ & 3.8 \\
\hline 40 & $\begin{array}{l}\text { Plocama calabrica (L.f.) } \\
\text { M.Backlund \& Thulin (Rubiaceae) }\end{array}$ & $\begin{array}{l}\text { Aerial } \\
\text { Parts }\end{array}$ & 284626 & $263.1 \pm 36.4$ & $447.7 \pm 182.1$ & 1.9 \\
\hline 41 & $\begin{array}{l}\text { Ptilostemon hispanicus (Lam.) } \\
\text { Greuter (Compositae) }\end{array}$ & $\begin{array}{l}\text { Aerial } \\
\text { Parts }\end{array}$ & 284620 & $276.6 \pm 13.6$ & $285.7 \pm 15.8$ & 1.0 \\
\hline 42 & $\begin{array}{l}\text { Ptilotrichum spinosum (L.) Boiss. } \\
\text { (Brassicaceae) }\end{array}$ & $\begin{array}{l}\text { Aerial } \\
\text { Parts }\end{array}$ & 284623 & $295.2 \pm 20.7$ & $531.7 \pm 320.5$ & 1.9 \\
\hline 43 & $\begin{array}{l}\text { Rhamnus myrtifolia Willk. } \\
\text { (Rhamnaceae) }\end{array}$ & Leaves & 284616 & $38.2 \pm 9.7$ & $183.9 \pm 27.9$ & 5.6 \\
\hline 44 & $\begin{array}{l}\text { Santolina chamaecyparissus L. } \\
\text { (Compositae) }\end{array}$ & $\begin{array}{l}\text { Flowering } \\
\text { aerial } \\
\text { parts }\end{array}$ & 284604 & $23.6 \pm 2.4$ & $22.8 \pm 2.2$ & 1.0 \\
\hline 45 & $\begin{array}{l}\text { Saponaria glutinosa M.Bieb. } \\
\text { (Caryophyllaceae) }\end{array}$ & $\begin{array}{l}\text { Whole } \\
\text { plant }\end{array}$ & 284622 & $87.1 \pm 41.2$ & $1.6 \pm 0.5$ & 0.03 \\
\hline 46 & $\begin{array}{l}\text { Scrophularia canina subsp. } \\
\text { crithmifolia (Boiss.) O.Bolòs \& } \\
\text { Vigo (Scrophulariaceae) }\end{array}$ & $\begin{array}{l}\text { Aerial } \\
\text { Parts }\end{array}$ & 284609 & $333.2 \pm 80.1$ & $462.6 \pm 211.6$ & 1.3 \\
\hline 47 & $\begin{array}{l}\text { Scrophularia canina subsp. } \\
\text { crithmifolia (Boiss.) O.Bolòs \& } \\
\text { Vigo (Scrophulariaceae) }\end{array}$ & Root & 284609 & $>1000$ & $>1000$ & N.D. \\
\hline 48 & $\begin{array}{l}\text { Sedum mucizonia (Ortega) Raym.- } \\
\text { Hamet (Crassulaceae) }\end{array}$ & $\begin{array}{l}\text { Whole } \\
\text { plant }\end{array}$ & 284624 & $877.3 \pm 268.9$ & $>1000$ & $>1.7$ \\
\hline 49 & Stachys germanica L. (Lamiaceae) & $\begin{array}{l}\text { Flowering } \\
\text { aerial } \\
\text { parts }\end{array}$ & 284610 & $301.8 \pm 9.5$ & $297.6 \pm 29.0$ & 1.0 \\
\hline 50 & $\begin{array}{l}\text { Teucrium lusitanicum Schreb. } \\
\text { (Lamiaceae) }\end{array}$ & $\begin{array}{l}\text { Aerial } \\
\text { Parts } \\
\end{array}$ & 284605 & $230.4 \pm 12.0$ & $207.4 \pm 13.9$ & 0.9 \\
\hline 51 & Thapsia villosa L. (Apiaceae) & $\begin{array}{l}\text { Flowering } \\
\text { aerial } \\
\text { parts }\end{array}$ & 284627 & $0.0018 \pm 0.0001$ & $0.010 \pm 0.004$ & 5.8 \\
\hline 52 & $\begin{array}{l}\text { Thymus baeticus Boiss. ex Lacaita } \\
\text { (Lamiaceae) }\end{array}$ & $\begin{array}{l}\text { Aerial } \\
\text { Parts }\end{array}$ & 284606 & $127.0 \pm 53.9$ & $219.9 \pm 23.9$ & 4.4 \\
\hline 53 & $\begin{array}{l}\text { Thymus granatensis Boiss. } \\
\text { (Lamiaceae) }\end{array}$ & $\begin{array}{l}\text { Aerial } \\
\text { Parts } \\
\end{array}$ & 284638 & $143.9 \pm 47.3$ & $683.1 \pm 327.8$ & 5.2 \\
\hline 54 & $\begin{array}{l}\text { Thymus granatensis Boiss. } \\
\text { (Lamiaceae) }\end{array}$ & Root & 284638 & $29.8 \pm 2.0$ & $271.6 \pm 62.2$ & 9.2 \\
\hline 55 & $\begin{array}{l}\text { Ulex baeticus Boiss. subsp. } \\
\text { baeticus (Leguminosae) }\end{array}$ & $\begin{array}{l}\text { Aerial } \\
\text { Parts } \\
\end{array}$ & 284611 & $204.5 \pm 19.1$ & $406.8 \pm 84.5$ & 2.0 \\
\hline
\end{tabular}




\begin{tabular}{|c|c|c|c|c|c|c|}
\hline & \multirow[b]{2}{*}{ Plant name (Family) } & \multirow[b]{2}{*}{ Part used } & \multirow{2}{*}{$\begin{array}{l}\text { Voucher } \\
\text { number } \\
\text { (SEV-) }\end{array}$} & \multicolumn{2}{|c|}{$\mathrm{IC}_{50}($ Mean \pm SEM, $\mu \mathrm{g} / \mathrm{ml})$} & \multirow[b]{2}{*}{ S.I. } \\
\hline & & & & $\begin{array}{l}\text { A549 } \\
\text { (Cancer) }\end{array}$ & $\begin{array}{l}\text { MRC-5 } \\
\text { (Normal) }\end{array}$ & \\
\hline 56 & $\begin{array}{l}\text { Verbascum thapsus subsp. } \\
\text { giganteum (Willk.) Nyman } \\
\text { (Scrophulariaceae) }\end{array}$ & Flowers & 284628 & $344.3 \pm 30.6$ & $>1000$ & $>3.0$ \\
\hline 57 & $\begin{array}{l}\text { Verbascum thapsus subsp. } \\
\text { giganteum (Willk.) Nyman } \\
\text { (Scrophulariaceae) }\end{array}$ & Leaves & 284628 & $359.2 \pm 56.1$ & $989.9 \pm 355.3$ & 2.8 \\
\hline & Cisplatin & - & - & $2.3 \pm 0.2$ & $6.7 \pm 1.1$ & 2.8 \\
\hline
\end{tabular}

S.I.: selectivity index (calculated as the average of the $\mathrm{IC}_{50}$ value in the normal cell line divided by the $\mathrm{IC}_{50}$ value in the cancer cell line obtained in each independent experiment). N.D.: not determined. 
Table 2. Cytotoxic activity of selected extracts and cisplatin on human cell lines (resazurin assay).

\begin{tabular}{|l|c|c|c|c|c|c|}
\hline & \multicolumn{6}{|c|}{ IC50 (Mean \pm SEM, $\boldsymbol{\mu g} / \mathbf{m L}$ ) } \\
\hline Cell line & $\mathbf{2 2}$ & $\mathbf{2 3}$ & $\mathbf{2 7}$ & $\mathbf{3 2}$ & $\mathbf{5 1}$ & Cisplatin \\
\hline VH10 & $>1000$ & $>100$ & $221.8 \pm 62.2$ & $6.9 \pm 1.3$ & $0.66 \pm 0.06$ & $3.4 \pm 0.1$ \\
\hline HepG2 & $>1000$ & $>100$ & $172.6 \pm 41.8$ & $13.7 \pm 4.6$ & $0.45 \pm 0.16$ & $1.3 \pm 0.2$ \\
\hline SW480 & $200.8 \pm 67.5$ & $138.7 \pm 60.0$ & $195.4 \pm 24.3$ & $6.3 \pm 1.2$ & $0.46 \pm 0.09$ & $0.5 \pm 0.2$ \\
\hline U2OS & $253.5 \pm 41.5$ & $119.4 \pm 100.8$ & $71.2 \pm 15.5$ & $6.9 \pm 2.0$ & $0.12 \pm 0.02$ & $1.1 \pm 0.2$ \\
\hline HeLa & $256.3 \pm 79.0$ & $181.8 \pm 37.0$ & $281.3 \pm 28.5$ & $5.3 \pm 0.2$ & $0.88 \pm 0.29$ & $1.3 \pm 0.1$ \\
\hline PC3 & $356.0 \pm 118.8$ & $>100$ & $420.7 \pm 46.9$ & $23.7 \pm 12.6$ & $0.76 \pm 0.33$ & $2.2 \pm 0.8$ \\
\hline MCF7 & $408.0 \pm 70.0$ & $>100$ & $403.0 \pm 19.7$ & $6.3 \pm 1.8$ & $0.69 \pm 0.12$ & $2.6 \pm 0.6$ \\
\hline NB4 & $0.032 \pm 0.002$ & $0.002 \pm 0.001$ & $221.8 \pm 29.6$ & $2.7 \pm 0.9$ & $0.11 \pm 0.03$ & $0.009 \pm 0.004$ \\
\hline HL-60 & $0.045 \pm 0.008$ & $0.002 \pm 0.001$ & $73.7 \pm 37.2$ & $9.0 \pm 2.3$ & $0.14 \pm 0.05$ & $0.04 \pm 0.04$ \\
\hline BJ-hTERT & $250.7 \pm 34.9$ & $10.6 \pm 9.3$ & $134.8 \pm 31.8$ & $11.1 \pm 3.0$ & $0.27 \pm 0.04$ & $0.40 \pm 0.08$ \\
\hline BJ-SV40T & $111.3 \pm 27.9$ & $0.7 \pm 0.2$ & $277.0 \pm 18.4$ & $11.3 \pm 0.3$ & $0.15 \pm 0.04$ & $0.20 \pm 0.06$ \\
\hline BJ-RASV12 & $0.9 \pm 0.2$ & $0.10 \pm 0.03$ & $254.6 \pm 30.3$ & $13.9 \pm 2.7$ & $0.05 \pm 0.01$ & $0.30 \pm 0.03$ \\
\hline
\end{tabular}

VH10 (Human skin non-malignant), HepG2 (Human hepatocellular carcinoma), SW480 (Human colon adenocarcinoma), U2OS (Human osteosarcoma), HeLa (Human cervical carcinoma), PC3 (Human prostate cancer), MCF7 (Human breast adenocarcinoma), NB4 (Human acute promyelocytic leukemia), HL-60 (Human acute promyelocytic leukemia), BJ-hTERT (hTERTimmortalized skin non-malignant BJ), BJ-SV40T (SV40T-transformed BJ-hTERT), BJ-RASV12 (H-RAS V12-transformed BJ-SV40T). Extract numbers (22, 23, 27, 32 and 51) can be identified from Table 1. 

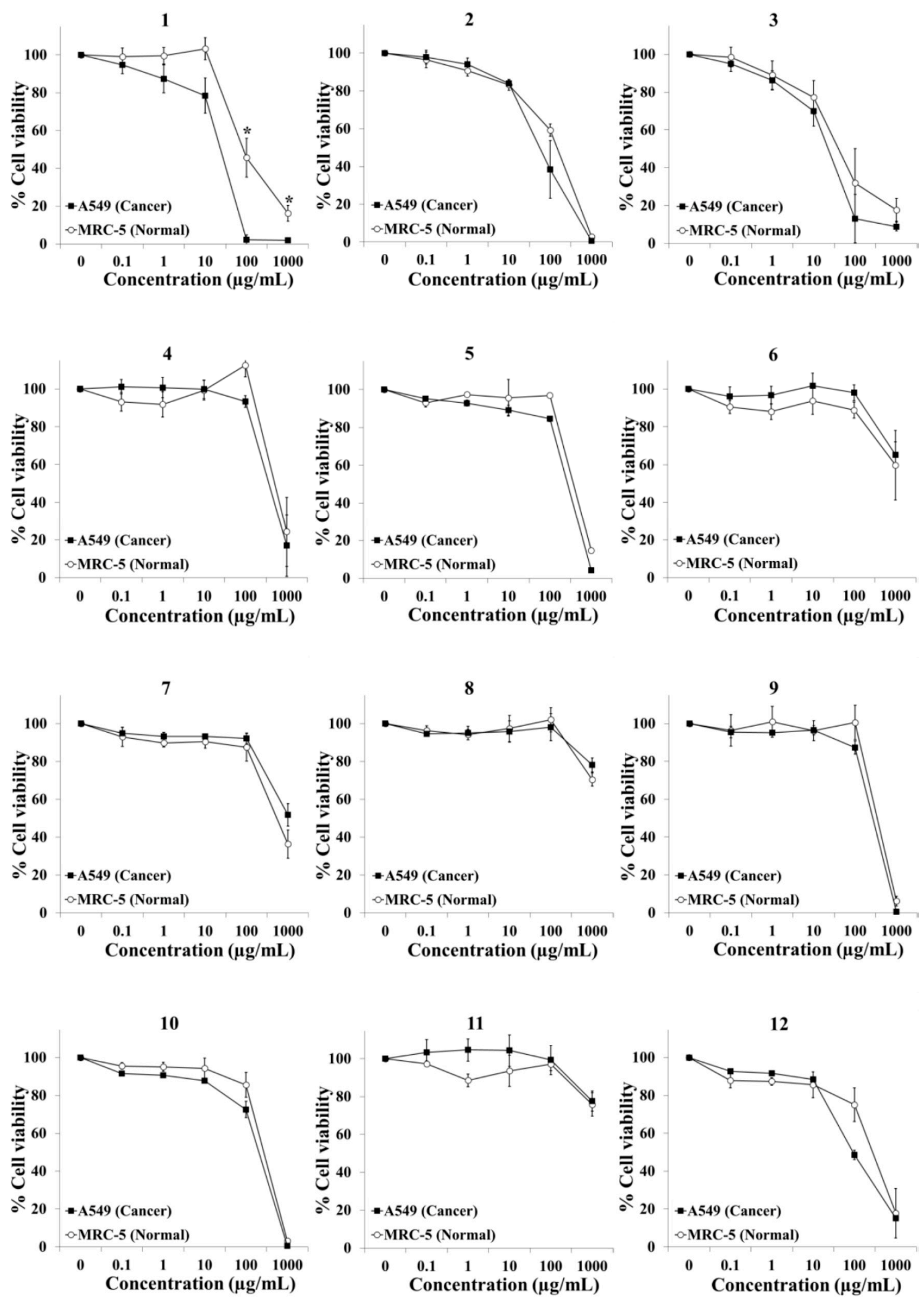

Figure 1. Evaluation of selective cytotoxicity activity of plant extracts 1-12 in A549 lung cancer cells and MRC5 lung normal cells. Cells were exposed to the extracts for $72 \mathrm{~h}$ and cell viability was estimated with the MTT assay. 

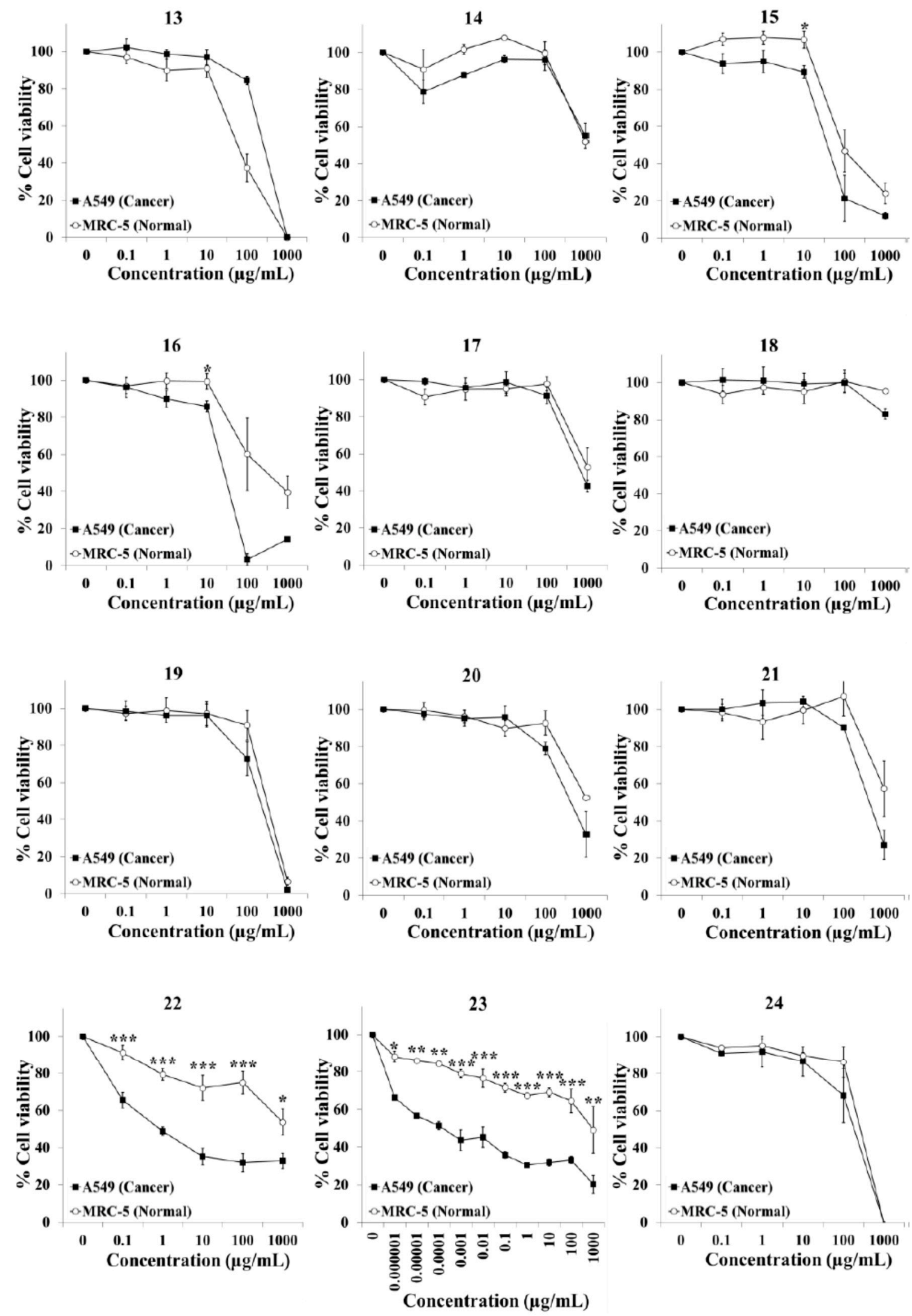

Figure 2. Evaluation of selective cytotoxicity activity of plant extracts 13-24 in A549 lung cancer cells and MRC5 lung normal cells. Cells were exposed to the extracts for $72 \mathrm{~h}$ and cell viability was estimated with the MTT assay. 

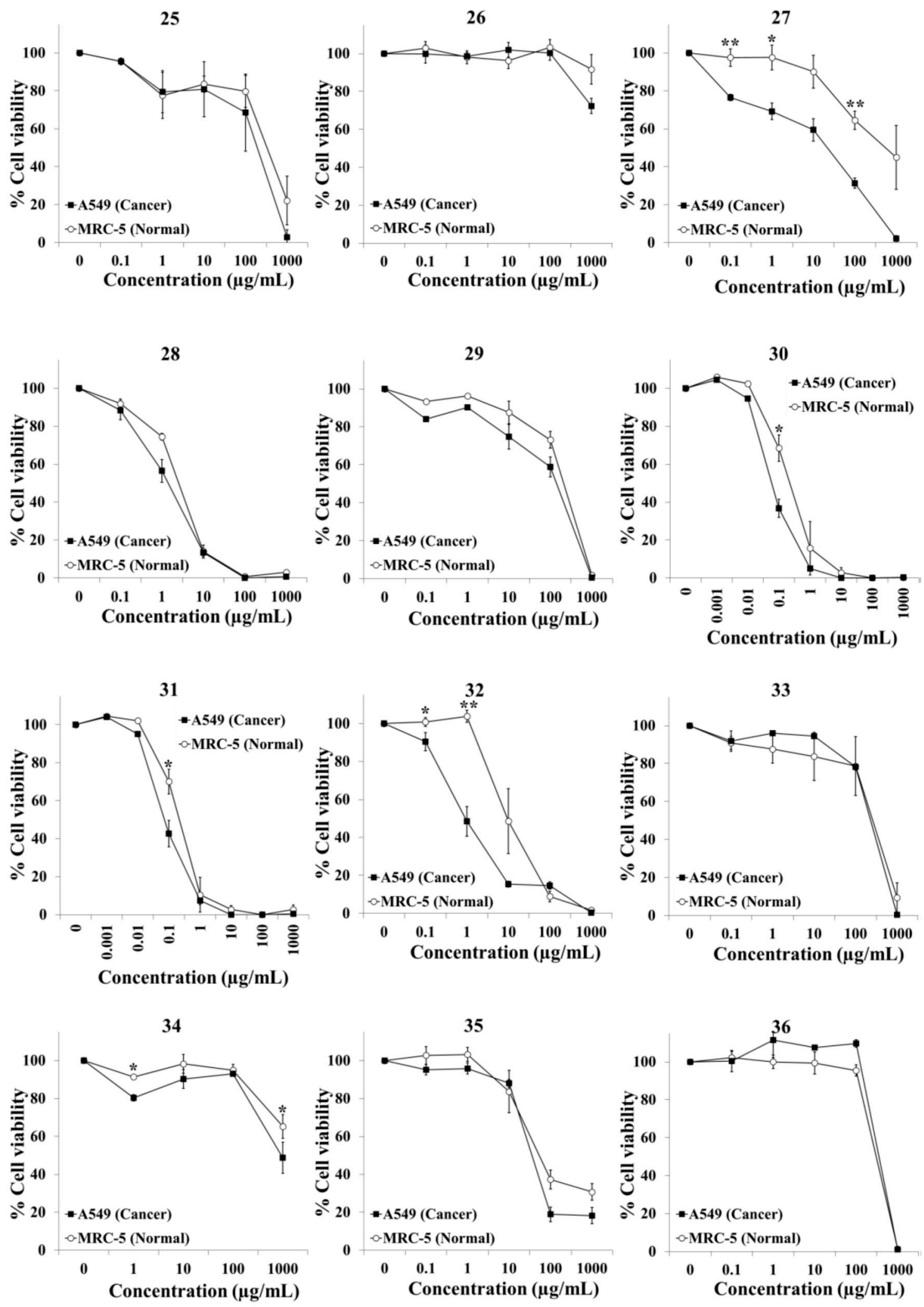

Figure 3. Evaluation of selective cytotoxicity activity of plant extracts 25-36 in A549 lung cancer cells and MRC5 lung normal cells. Cells were exposed to the extracts for $72 \mathrm{~h}$ and cell viability was estimated with the MTT assay. 

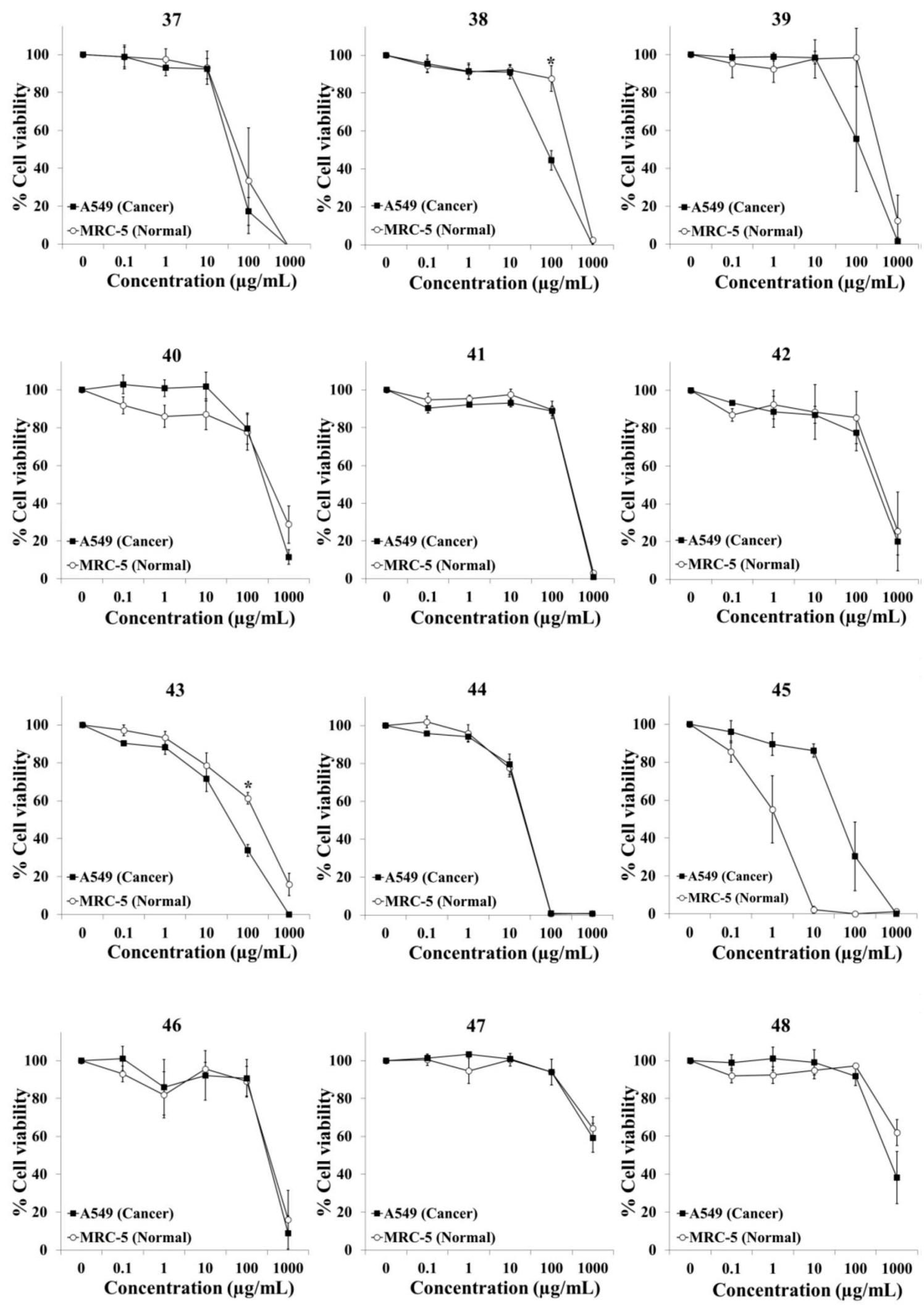

Figure 4. Evaluation of selective cytotoxicity activity of plant extracts 37-48 in A549 lung cancer cells and MRC5 lung normal cells. Cells were exposed to the extracts for $72 \mathrm{~h}$ and cell viability was estimated with the MTT assay. 

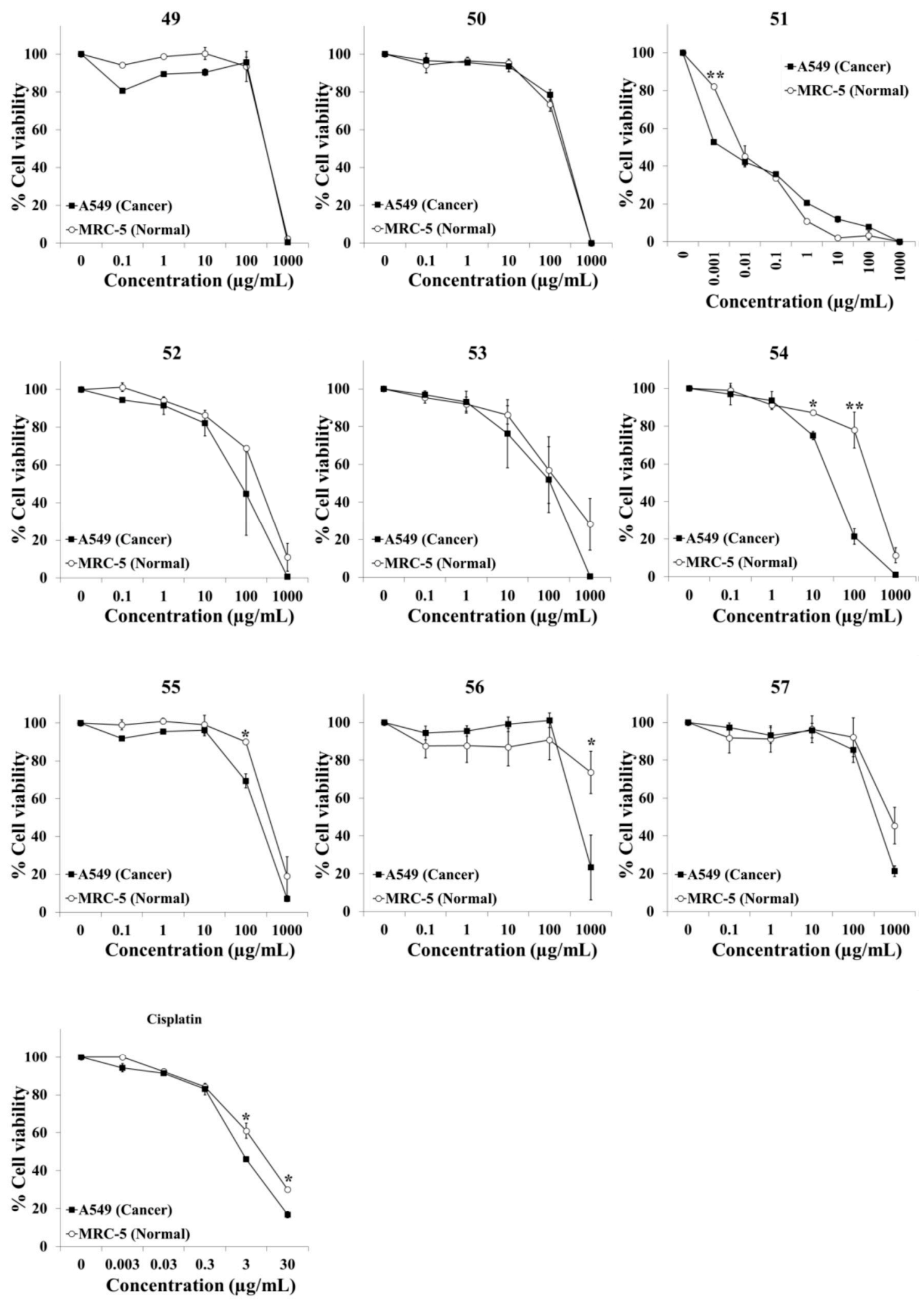

Figure 5. Evaluation of selective cytotoxicity activity of plant extracts 49-57 and cisplatin in A549 lung cancer cells and MRC5 lung normal cells. Cells were exposed to the extracts and cisplatin for $72 \mathrm{~h}$ and cell viability was estimated with the MTT assay. 


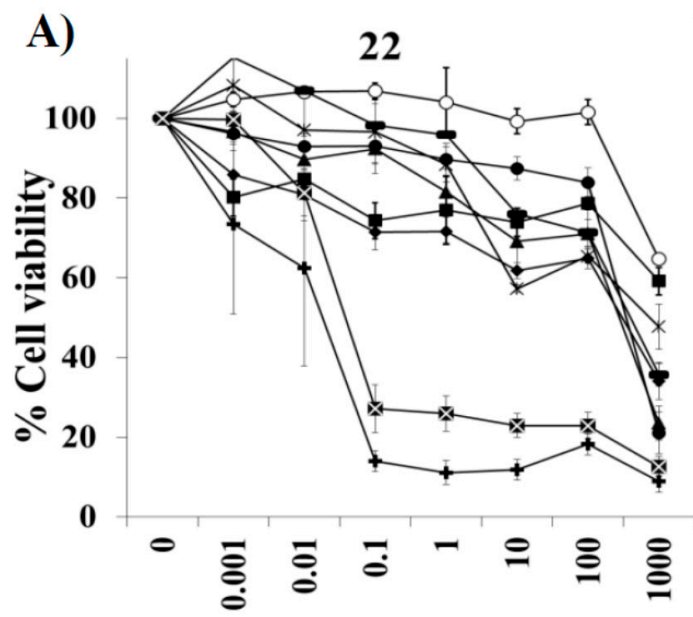

Concentration $(\mu \mathrm{g} / \mathrm{mL})$

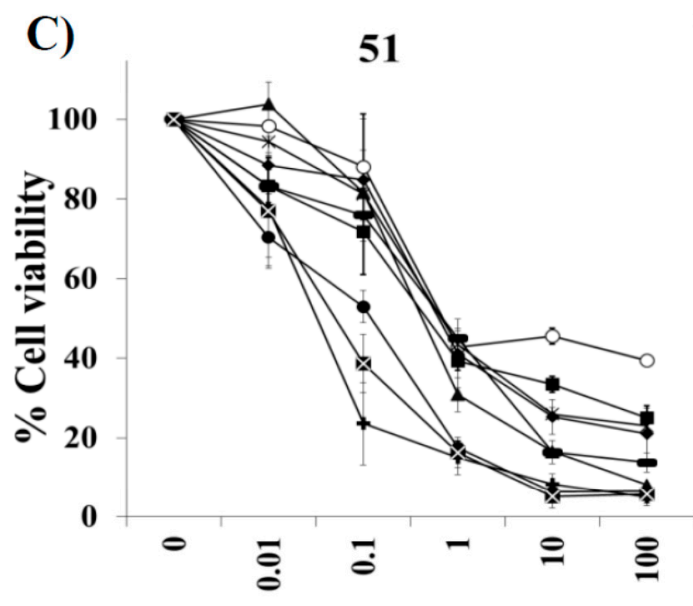

Concentration $(\mu \mathrm{g} / \mathrm{mL})$

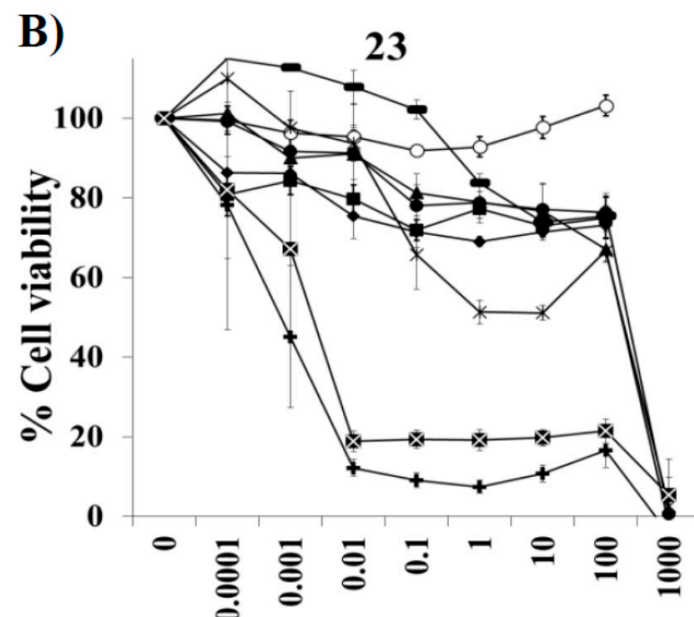

Concentration $(\mu \mathrm{g} / \mathrm{mL})$

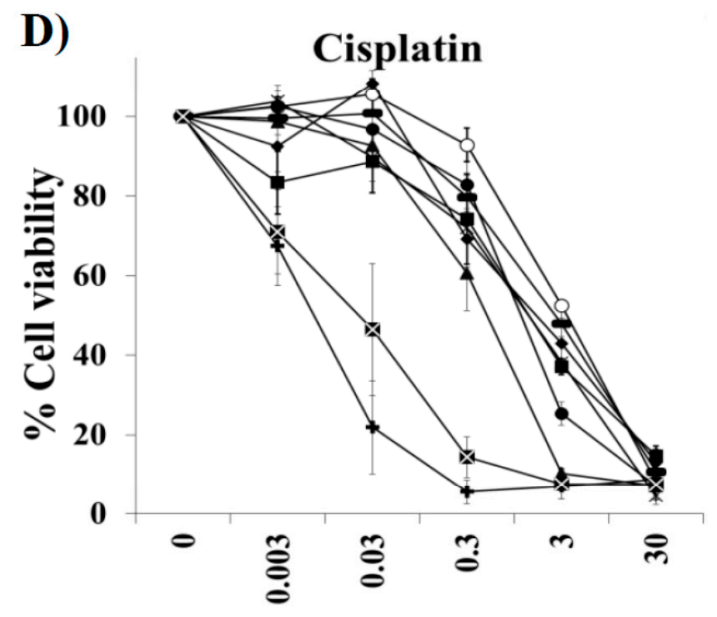

Concentration $(\mu \mathrm{g} / \mathrm{mL})$

\footnotetext{
- VH-10 (Skin normal) -U2OS (Osteosarcoma) -MCF7 (Breast adenocarcinoma)

-HepG2 (Hepatocarcinoma) * HeLa (Cervical carcinoma) + NB4 (Acute promyelocytic leukemia)

$\leftarrow$ SW480 (Colon cancer) $\quad \rightarrow$ PC3 (Prostate cancer) $\quad \rightarrow$ HL-60 (Acute promyelocytic leukemia)
}

Figure 6. Evaluation of selective cytotoxic activity of plant extracts 22, 23 and $\mathbf{5 1}$ and cisplatin in a normal skin cell line, 6 cancer cell lines derived from solid tumors of different tissues (liver, colon, bone, cervix, prostate and breast) and 2 acute promyelocytic leukemia cell lines. Cells were exposed for 72 hours to the extracts or cisplatin and cell viability was estimated with the resazurin assay. 